\title{
Isolation and Identification of Diterpenoid Anti-Blast Substances Produced in the Blast-infected Rice Leaves*
}

\author{
Nobuaki MatsuYama** and Satoshi WaKimoto**
}

\begin{abstract}
Some diterpenoid anti-blast substances which were found in blast-infected rice leaves and detectable by GLC (OV-17) were isolated and purified by using LC, preparative HPLC and TLCs. These substances were analyzed by GC-MS, MS and HR-MS. The substance 17-3M was identified as $\mathrm{S}-1\left(\mathrm{C}_{20} \mathrm{H}_{32} \mathrm{O}_{2}\right.$, Mole. Wt. 304) which was previously reported. The substance $14-6 \mathrm{M}$ was analyzed as $\mathrm{C}_{20} \mathrm{H}_{30} \mathrm{O}_{2}$, Mole. Wt. 302. The molecular weight of the substance 14-7M was 302 and it was assumed as $\mathrm{C}_{20} \mathrm{H}_{30} \mathrm{O}_{2}$. The substance $12-7 \mathrm{M}$ was also detectable by GLC at similar retention time with other substances and distinctly different from Oryzalexins which were formerly reported. The analyses of the fractions from HPLC indicated the existence of several derivatives which could be novel substances.
\end{abstract}

(Received December 23, 1987)

Key words: phytoalexins, S-1 derivatives purification, diterpenoids, rice-blast resistance.

\section{INTRODUCTION}

During the studies on the existence of Momilactones A and B in healthy and blast-infected rice leaves ${ }^{16}$, the authors detected a distinct single peak at the retension time (Rt) $9.9 \mathrm{~min}$ on gas-liquid chromatography (GLC) ${ }^{18}$. This peak was only detected on the chromatogram of the sample from the rice leaves infected with the blast fungus Pyricularia oryzae Cav. but not from the healthy check leaves ${ }^{18)}$. A substance (S-1) which resemble to but clearly different from Momilactones $A, B^{3-5,7-9)}$, Oryzalexins $A, B$ and $C^{1,2)}$ was isolated and analyzed by gas-liquid chromatography mass spectrometry (GC-MS), mass spectrometry (MS) and high resonance mass spectrometry (HR-MS) ${ }^{19)}$. The chemical formula of this substance was $\mathrm{C}_{20} \mathrm{H}_{32} \mathrm{O}_{2}$ and the molecular weight was $304^{19)}$.

While, the results of a direct GC-MS analysis of the peak on the GLC and the bioautography with TLCs showed the existence of the derivatives of S-1. To isolate and identify these derivatives, this experiment was conducted. A part of this work was reported elsewhere ${ }^{21}$.

\section{MATERIALS AND METHODS}

Plants and inoculum. Rice cultivar Aichi-asahi was routinely raised and plants were inoculated at 7 th leaf stage with the blast fungus Pyricularia oryzae Cav. isolate Naga 69-150 (race 007).

Sampling of leaves and extraction. Seven days after inoculation 5, 6 and 7th (uppermost) leaves were collected. Thirty-five gram of the sample leaves was chopped with scissors into $500 \mathrm{ml}$ of $70 \%$ aqueous methanol and homogenized by Physcotron homogenizer after keeping for $3 \mathrm{~min}$ in boiling water bath ${ }^{23)}$. The extract was filtered and concentrated in vacuo to ca.

\footnotetext{
* This study was supported in part by a Grant-in-Aid from the Ministry of Education, Science and Culture of Japan (No. 59480041).

** Faculty of Agriculture, Kyushu University, Fukuoka 812, Japan～九州大学晨学部
} 
$150 \mathrm{ml}$. Then, the sample was shaken with $300 \mathrm{ml}$ of petroleum ether twice in the separation funnel for $5 \mathrm{~min}$. The petroleum ether layers were separated and concentrated.

Purification. The petroleum ether was completely eliminated by $\mathrm{N}_{2}$ gas blowing. The residue was dissolved in $5 \mathrm{ml}$ of $90 \%$ methanol and subjected to the liquid chromatography (LC) with Lobar column (Merck RP-18 B type). The LC was carried out by $90 \%$ methanol and the eluate was fractionated every $20 \mathrm{~min}$ (ca. $9.5 \mathrm{ml}$ ) to the tubes. The tube No. 12-18 contained the substances which appear around Rt $9.9 \mathrm{~min}$ on GLC (OV-17). Each fraction was concentrated and subjected to preparative high performance liquid chromatography (PHPLC) (Gilson Model 303, Column: M\&S pack C18-B) and eluted with $80 \%$ methanol monitoring at $210 \mathrm{~nm}$, respectively. Each peak area on the chromatogram was collected directly. Since these fractions still contained many contaminants, further purification by the series of thin layer chromatography (TLC) with Silica gel 60 plate (Merck) was conducted. The developing solvents were as follows: chloroform-ethanol $9: 1$, ethyl acetate-carbon tetrachloride $6: 4$, cyclohexane-dioxane $7: 3$ $(\mathrm{v} / \mathrm{v})$. The guide spots were detected by the spray of vanillin-sulfuric acid solution at room temperature. The substances were visualized as purple to blue color which is the characteristic of terpenoids. The corresponding area where was covered with wrapping aluminium foil and polyethylene film at the detection of the guide spots was scraped and the substance was eluted with methanol. The substances after TLCs purifications were subjected repeatedly to PHPLC and finally purified. The monitoring of the substances was conducted by GLC (OV-17), visualization with vanillin-sulfuric acid and biological activities ${ }^{18}$ during the course of purification.

GLC analysis. GLC was conducted by Shimazu GC-7AG apparatus with FID by using OV-17 column ( $1 \%$ loading on Gas Chrom $Q, 100-120$ mesh, in silanized glass column $0.3 \times 150$ $\mathrm{cm}$ ) under the conditions of $210 \mathrm{C}$ column temperature and $\mathrm{N}_{2}$ gas flow rate $30 \mathrm{ml} / \mathrm{min}$.

GC-MS, MS and HR-MS analyses. GC-MS was conducted by JEOL JMS-DX300 with Packard Ultra-1 capillary column $(0.2 \mathrm{~mm} \times 25 \mathrm{~m})$. MS (direct insertion) was conducted by JEOL JMS-D300 and HR-MS was carried out by JEOL JMS-DX300 (JMA 3,500 data system).

\section{RESULTS AND DISCUSSION}

The production of the phytoalexin-like substances in blast-infected rice leaves have been well documented by many workers ${ }^{1-5,7,11,16,18-25,27-29)}$. Recently, Cartwright et al. ${ }^{3-5)}$ reported that

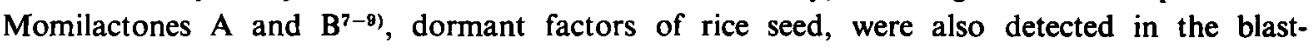
infected rice leaves. They imagined the close association of these substances with the blast resistance because of their strong inhibitory activities to spore germination of blast fungus Pyricularia oryzae Cav. ${ }^{3-5,28,29)}$. However, the authors couldn't detect any Momilactones in both of infected and healthy leaves ${ }^{16}$. During the studies on Momilactones, the authors found anti-blast substances which were different from them ${ }^{16}$. One of them was isolated, purified and analyzed by GC-MS, MS and HR-MS ${ }^{19}$. The chemical formula and molecular weight were $\mathrm{C}_{20} \mathrm{H}_{32} \mathrm{O}_{2}$ and 304, respectively. This substance was apparently different from Oryzalexin A,B and $\mathrm{C}$ which were formerly reported by Akatsuka et al ${ }^{1,2)}$ This novel diterpenoid showed a complete inhibition of spore germination at $2.2 \times 10^{-4} \mathrm{M}$ and was designated as $\mathrm{S}-1^{18,19)}$. This substance was seemed to be identical with Oryzalexin $D$ which was reported as 3,7-dihydroxy(+)-sandaracopimaradiene by Sekido et al. ${ }^{24)}$, recently.

Gas-liquid chromatograms (OV-17) of the crude extracts from blast-infected and healthy check leaves were distinctly different (Fig. 1). Distinct single peak appeared at Rt 9.9 min in case of the sample from blast-infected leaves. The direct analysis of this peak by GC-MS indicated the existence of several derivatives of $S-1$ which show a similar retention time. To isolate these derivatives, LC, preparative HPLC and TLCs were conducted. The eluates (Tube No. 1218) of liquid chromatography with Lobar column (Merck RP-18) contained substances which appeared around Rt 9.9 min on GLC. The eluate in each tube was subjected separately to the preparative HPLC. The elution patterns were summarized in Fig. 2. The shadowed peaks in 

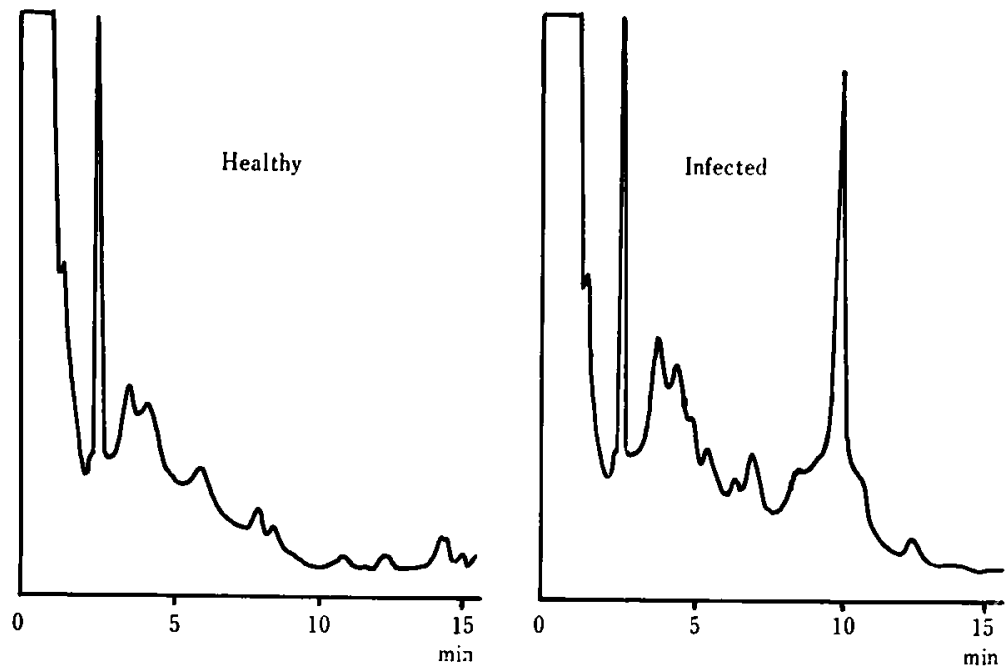

Fig. 1. Gas liquid chromatograms of the crude extracts from healthy (left) and blast-infected (right) rice leaves. GLC (OV-17, $210 \mathrm{C}$ column temperature, $\mathrm{N}_{2} 30 \mathrm{ml} / \mathrm{min}$. FID).

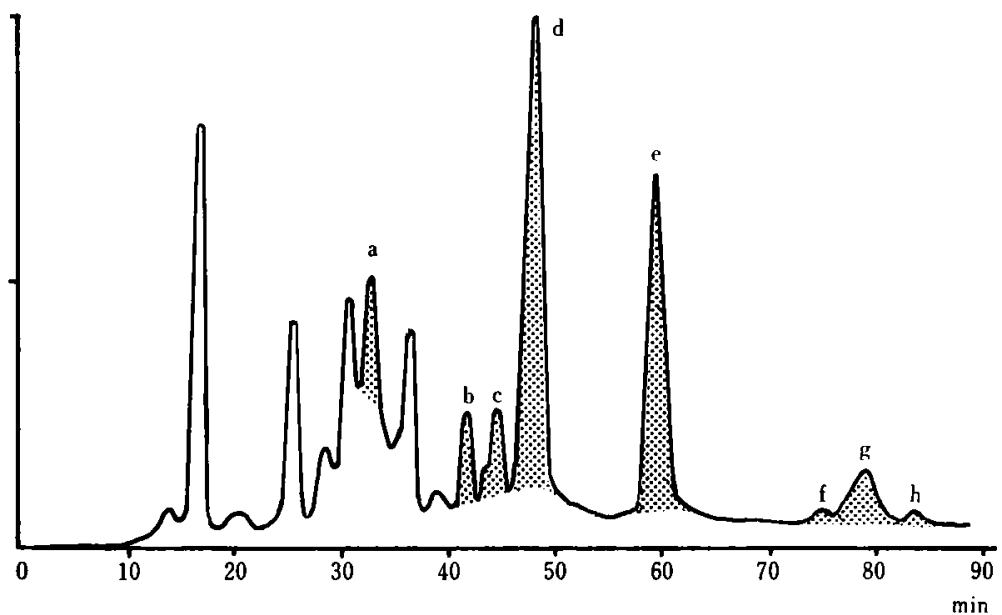

Fig. 2. High performance liquid chromatography (preparative) of the sample from the blastinfected rice leaves. Shadowed peaks contained the substances which appeared around Rt 9.9 min on GLC (OV-17). Monitored at $210 \mathrm{~nm}$.

Fig. 2 indicate the existence of the substances which show a similar retention time with S-1 on GLC (OV-17). Each shadowed peak area was separated and concentrated in vacuo and subjected to three series of TLCs, respectively.

The substance 17-3M was easily isolated and purified from the fraction of $\mathrm{Rt} 78 \mathrm{~min}$ on preparative HPLC ( $\mathrm{g}$ in Fig. 2). This substance was identified as $\mathrm{S}-1\left(\mathrm{C}_{20} \mathrm{H}_{32} \mathrm{O}_{2}\right.$, Mole. Wt. 304). The substance 14-6M which was contained in the fraction at Rt $44 \mathrm{~min}$ (c in Fig. 2) was also easily purified and analyzed as $\mathrm{C}_{20} \mathrm{H}_{30} \mathrm{O}_{2}$, Mole. Wt. 302 (Fig. 3a). While, the fraction at Rt 48 min ( $d$ in Fig. 2) contained many substances and the purification of bioactive substance was not easy. Although the substance 14-7M seemed to be a single substance on TLCs used, the substance was still contaminated showing shoulder in the main peak on GLC (OV-17). The 14-7M was finally isolated on GLC with Packard Ultra-1 (25 m capillary column) and then analyzed 


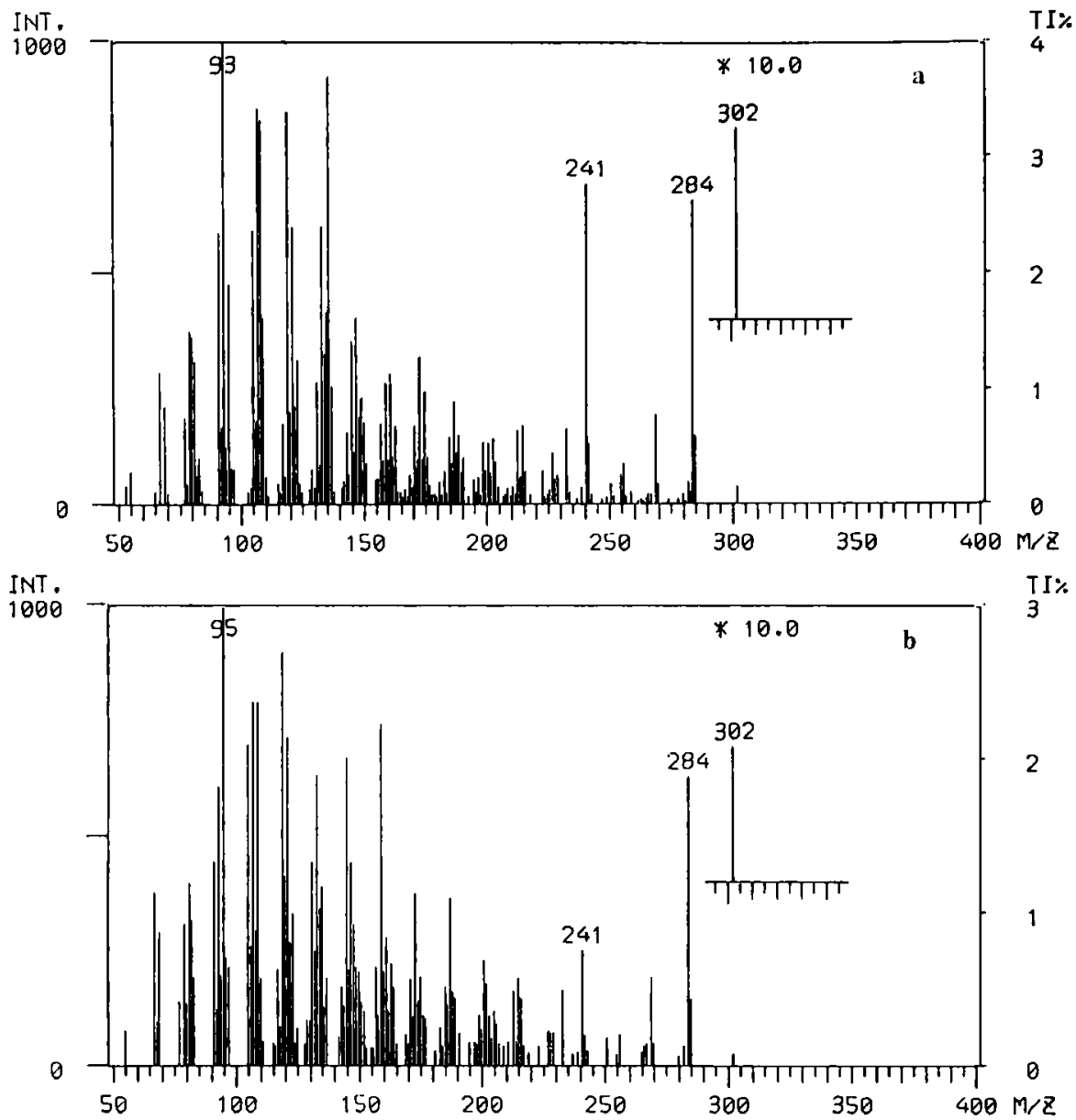

Fig. 3. Mass spectra observed by GC-MS, using JEOL DX300 (Column: Packard Ultra-1, 0.2 $\mathrm{mm} \times 25 \mathrm{~m}$ capillary).

(a) $14-6 \mathrm{M}$, (b) $14-7 \mathrm{M}$.

by GC-MS. The molecular weight of this substance was decided as 302 (Fig. 3b) and the molecular formula was assumed as $\mathrm{C}_{20} \mathrm{H}_{30} \mathrm{O}_{2}$. From the results of TLC with benzene-ethyl acetate $10: 1$ which was used originally by Akatsuka et al..$^{1,2)}$, it was decided that $14-6 \mathrm{M}$ was identical with Oryzalexin A and 14-7M was identical with Oryzalexin B.

While, the substance 12-7M which was isolated from the fraction at Rt $33 \mathrm{~min}$ (a in Fig. 2) was apparently different from the Oryzalexins ${ }^{1,2,24}$. By the result of GC-MS analysis, this substance was assumed to be a substance of Mole. Wt. 286. But final conclusion will be done after further studies.

As shown in Fig. 2 and Table 1, there still exist several substances which appear around Rt 9.9 min on GLC (OV-17) and show the anti-blast activities.

Although the role of these novel diterpenoids on the blast resistance are still under investigation, the data obtained up to date ${ }^{20)}$ support our early postulations ${ }^{18-20)}$ that these substances might not associate at early stage of the infection but rather associate with limiting lesion enlargement in aged leaves. The dynamic shifts of physiological situation of host cells after the recognition of parasites, such as the alteration of enzyme activities ${ }^{14,15}$, accumulation of the anti-blast substances ${ }^{1-6,10,11,18-25)}$ and the production of physical barriers ${ }^{12,13}$ have been documented. These phenomena will undoubtedly associate with the resistance. However, more rapid 
Table 1. The chemical properties of the anti-blast sutstances isolated from blast-infected rice leaves

\begin{tabular}{crccccc}
\hline \multirow{2}{*}{ Substance } & \multicolumn{3}{c}{ Retention time (min) } & TLC(Rf) & $\begin{array}{c}\text { Molecular } \\
\text { weight }\end{array}$ & $\begin{array}{c}\text { Molecular } \\
\text { formula }\end{array}$ \\
\cline { 2 - 4 } & GLC & HPLC & PHPLC & & & \\
\hline $12-7 \mathrm{M}$ & 10.08 & 5.2 & 33 & 0.58 & N.D & N.D \\
$14-6 \mathrm{M}$ & 10.10 & 7.6 & 44 & 0.62 & 302 & $\mathrm{C}_{20} \mathrm{H}_{30} \mathrm{O}_{2}$ \\
$14-7 \mathrm{M}$ & 9.89 & 8.5 & 48 & 0.65 & 302 & $\left.\mathrm{C}_{20} \mathrm{H}_{30} \mathrm{O}_{2}{ }^{\mathrm{a}}\right)$ \\
$17-3 \mathrm{M}$ & 9.89 & 11.5 & 78 & 0.52 & 304 & $\mathrm{C}_{20} \mathrm{H}_{32} \mathrm{O}_{2}$ \\
\hline
\end{tabular}

a) Since $14-7 \mathrm{M}$ was not analyzed by HR-MS, the molecular formula was assumed by the result of GCMS.

GLC: OV-17 column, HPLC: M\&S Pack C-18, PHPLC: M\&S Pack C-18 (preparative)

TLC: Chloroform-Ethanol $(9: 1 \mathrm{v} / \mathrm{v})$.

N.D: Not determined.

responses such as the generation of active oxygens ${ }^{6,17,26)}$ after invasion of the parasite should not be overlooked and its relation with the production of the anti-blast substances stated in this report should be investigated in future studies.

The authors are grateful to Drs. T. Komori, K. Matsuyama and R. Isobe, Faculty of Pharmaceutical Sciences, Kyushu University for their many advices and mass-spectrometry.

\section{Literature cited}

1. Akatsuka, T., Kodama, O., Kato, H., Kono, Y. and Takeuchi, S. (1983). Agric. Biol. Chem. 47: 445-447.

2. Akatsuka, T., Kodama, O., Sekido, H., Kono, Y. and Takeuchi, S. (1985). Ibid. 49: 1689-1694.

3. Cartwright, D.W., Langcake, P., Pryce, R.J., Leworthy, D.P. and Ride, J.P. (1977). Nature 267: 511-513.

4. Cartwright, D.W., Langcake, P. and Ride, J.P. (1980). Physiol. Plant Pathol. 17: 259-267.

5. Cartwright, D.W., Langcake, P., Pryce, R.J., Leworthy, D.P. and Ride, J.P. (1981). Phytochemistry 20: 535-537.

6. Haga, M., Sekizawa, Y., Ichikawa, M., Hiramatsu, H., Hamamoto, A., Takino, Y. and Ameyama, M. (1986). Agric. Biol. Chem. 50: 1427-1436.

7. Kato, T., Kabuto, C., Sasaki, N., Tsunakawa, M., Aizawa, H., Fujita, K., Kato, Y. and Kitahara, Y. (1973). Tetrahedron Lett. 39: 3861-3864.

8. Kato, T., Aizawa, H., Tsunakawa, M., Sasaki, N., Kitahara, Y. and Takahashi, N. (1977). Jour. Chem. Soc., Perkin Transactions I: 250-254.

9. Kato, T., Tsunakawa, M., Sasaki, N., Aizawa, H., Fujita, K., Kitahara, Y. and Takahashi, N. (1977). Phytochemistry 16: 45-48.

10. Kato, T., Yamaguchi, Y., Uyehara, T., Yokoyama, T., Namai, T. and Yamanaka, S. (1983). Naturwissenschaften 70: S. 200-201.

11. Kato, T., Yamaguchi, Y., Uyehara, T., Yokoyama, T., Namai, T. and Yamanaka, S. (1983). Tetrahedron Lett. 24 : 4715-4718.

12. Matsuyama, N. and Dimond, A.E. (1973). Phytopathology 63: 1202-1203.

13. Matsuyama, N. (1975). Ann. Phytopath. Soc. Japan 41: 56-61.

14. Matsuyama, N. and Kozaka, T. (1981). Ibid. 47: 654-661.

15. Matsuyama, N. (1982). Ibid. 48: 217-219.

16. Matsuyama, N. (1983). Ibid. 49: 200-205.

17. Matsuyama, N. (1983). Ibid. 49: 270-273.

18. Matsuyama, N. and Wakimoto, S. (1984). Ibid. 50: 379-382.

19. Matsuyama, N. and Wakimoto, S. (1985). Ibid. 51: 498-500.

20. Matsuyama, N. and Wakimoto, S. (1987). Jbid. 53: 449-453.

21. Matsuyama, N. and Wakimoto, S. (1988). Ibid. 54: In press.

22. Nasuda, K. (1973). Special Bull. Fukui Agric. Exp. Stn. No. 3: 1-167. 
23. Ohata, K. and Kozaka, T. (1967). Bull. Natl. Inst. Agric. Sci. Series C, No. 21: 111-132.

24. Sekido, H., Endo, T., Suga, R., Kodama, O., Akatsuka, T., Kono, Y. and Takeuchi, S. (1986). J. Pesticide Sci. $11:$ 369-372.

25. Sekizawa, Y., Shimura, M., Suzuki, A. and Iwata, M. (1981). Agric. Biol. Chem. 45: 1437-1439.

26. Sekizawa, Y., Haga, M., Hirabayashi, E., Takeuchi, N. and Takino, Y. (1987). Ibid. 51: 763-770.

27. Shimura, M., Iwata, M., Tashiro, N., Sekizawa, Y., Suzuki, Y., Mase, S. and Watanabe, T. (1981). Ibid. 45: 1431-1435.

28. Watanabe, M., Sakaniwa, S., Uchiyama, M. and Abe, H. (1979). Ann. Phytopath. Soc. Japan 45: 509-511.

29. Yamanaka, S., Namai, T., Kato, T., Sasaki, N. and Takahashi, N. (1980). Ibid. 46: $494-498$.

\section{和 文 摘 要}

松山宣明・脇本 哲：いもち病感染葉中に形成されるジテルペノイド采抗いもち病菌物質の単離と同定

いもち病菌接種イネ葉中には, GLC (OV-17, 210C, $\mathrm{N}_{2}$ 流量 $\left.30 \mathrm{ml} / \mathrm{min}\right)$ によりRt $9.9 \mathrm{~min}$ 付近に検出可 能な抗いもち病菌物質が多数形成される。LC，分取型 HPLC，3 種の TLCにより純化された試料につい て，GC-MS, MS, HR-MSにより分析を行い物質の同定を試みた。分取型 HPLC 上, 78 min に出現する ピーク部分から精製された 17-3 M は, 既報のS-1 $\left(\mathrm{C}_{20} \mathrm{H}_{32} \mathrm{O}_{2}\right.$, 分子量 304) であり， $44 \mathrm{~min}$ に現れるピー ク部から得られた 14-6 M は HR-MS 分析の結果から，分子式 $\mathrm{C}_{20} \mathrm{H}_{30} \mathrm{O}_{2}$ ，分子量 302 と同定された。 $48 \mathrm{~min}$ 部からの 14-7 M は同じく分子量 302 の物質であり，分子式 $\mathrm{C}_{20} \mathrm{H}_{30} \mathrm{O}_{2}$ と推定された。一方, $33 \mathrm{~min}$ 部からの 12-7 M は新規物質と考学られ, 現在分析中である。また，HPLC，GLCの結果から，接種葉から の抽出分画中には，さらに数種類の未同定の抗いもら病菌物質が存在することが明らかになった。これらの 物質群は，現在のところ葉組織の加柃に伴う病斑払大阻止現象に密接に関与していると推定されるが，詳細 については現在さらに検討中である。 